\title{
PALÆSTRA i \\ O-D-I-N's træningsanlæg
}

Af Ole Worm

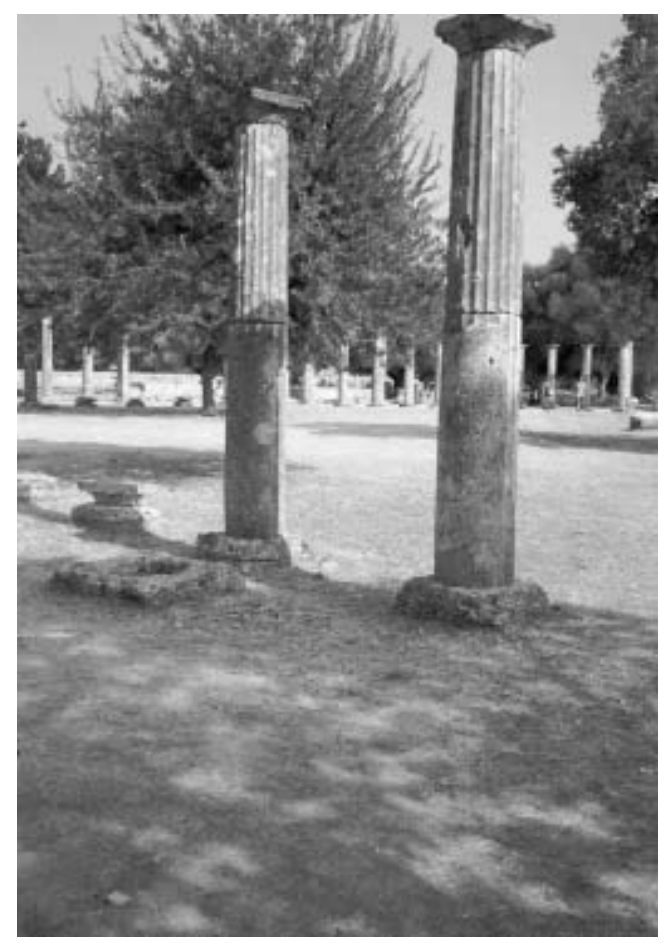

Figur 1: Palcestra i Olympia set fra Nord$\phi$ st.

OL-deltagelse kan i dag af og til være en paradoksal oplevelse. At komme, se og falde uden for eller helt igennem er ikke meningen og var utænkeligt ved de antikke olympiske lege. Stedets kompetente myndighed havde deltagerne under disciplinering og kultivering og påtog sig hermed det ansvar, at præstationerne skulle tjene til eksempel på det gode liv. Dette var ikke et decentralt ærinde. At deltage var i en højere sags tjeneste. Forudsætningen var et månedlangt træningsophold på stedet. Stedet var palæstra; en bryde- og kampplads.

Denne artikel søger dette specielle rum på disse få steder, hvor antikkens atleter kultiverede sig med æreskrans, stephanos, som bevis og symbol på heroisk udødelighed ved fire panegyriske stævner i Olympia-Delfi-Isthmia-Nemea (O-D-I-N). Disse »stefaniske« konkurrencesteders nærhed ses på kortet i figur 2 .

Stefaneforos var de kamplege, hvor kampprisen var en sejrskrans. En del af den afsluttende træning fandt sted $i$ et af sportens træningsrum, palæstra, i Olympia i landskabet Elis, Delfi i Fokis, Nemea i Ar-

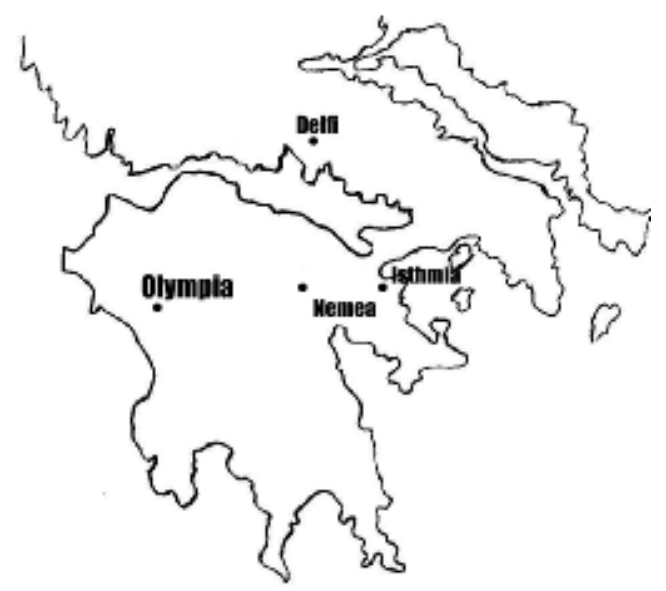

Figur 2: De fire »stefaniske" konkurrecesteder. 
golis og Isthmia ved Korinth, men uden bystatens hverdagsfunktion. O-D-I-Ns palæstra skal ses i samme kontekstuelle forbindelse, hvor hverdagsmennesket får stillet egne bestræbelser på at skabe et godt liv over for den rendyrkede form hos atleterne.

Artiklen er ikke resultatet af feltarkæologisk arbejde, men derimod litteraturstudier. Som dokumentation for den antikke brug af palæstra/gymnasion er anvendt udvalgte græske indskrifter, som er hentet fra The Perseus Digital Library. ${ }^{1}$ Hvad er afdækket, hvornår palæstrabygningerne etableredes og hvad de rummede, søges besvaret i denne artikel.

\section{O-D-I-N-et fallesgrask udtryk}

De fire store fællesgræske fester er omtalt og fremhævet med særlig klang af forfatteren Pindar i det 5. århundrede før vor tidsregning (f.v.t.).

»...folkeforsamlingerne [panegyris] blandt hellenerne, nemlig Isthmia, og Nemea og Olympia og Pythia ${ }^{2}$

Ud fra rekonstruerede sejrslister, indskrifter på basis af opstillede statuer og litterære tekster udkrystalliseres disse festivals som havende denne specielle »stefaniske « status. En del topatleter som Milon fra Kroton i midten af det 6. århundrede f.v.t. og Diagoras fra Rhodos 100 år senere er af episke digtere særlig blevet fremhævet ved at have sejret ved alle disse fire bestemte festivals. Det er imidlertid først i det 2. århundrede efter vor tidsregning (e.v.t.), at selve titlen periodonikere, som udtryk for denne sejrsperiode, periodo-nikes, forekommer. ${ }^{3}$

Hvor ideen til de moderne olympiske lege er undfanget i forsøget på at fastholde og udvikle centrale værdier for industrialiseringens tidsalder og i dag udtrykker dennes og sportens globalisering, var de panegyriske festforsamlinger og medfølgende festspil udtryk for et menneskes ultimative rollespil i håbet om at få skikkelse efter $\mathrm{d} \varnothing$ den. Ikke uden grund bivånede gudinden Demeter, der skabte frugtbart liv og »frugten $\ll$ Kore, de heroiske præstationer. ${ }^{4}$

Betydningsrækkenfølgen for disse fire periodebestemte store folkefester var O-D-I-N. ${ }^{5}$ Sport og musik i en kultisk ramme betegnes også som panhellenske lege. Lidt af en tilsnigelse, idet begrebet panhellenismen er et senere anvendt begreb. ${ }^{6}$ Fællesgræsk er derfor mere i tråd med tiden, idet ideen var tænkt og ønsket, måske sagt, men ikke politisk proklameret før den tidlige kejsertid. $^{7}$

De Olympiske Lege starter efter tilbageregning fra rekonstruerede sejrslister traditionelt i 776 f.v.t. ${ }^{8}$ En del materiale - lovgiveren Solon (ca. 630 - ca. 560 f.v.t.), kronografer $^{9}$ og få arkæologiske levn fra de første beskedne konkurrenceanlæg ${ }^{10}-$ peger i retning af, at de tre $\varnothing$ vrige helligdomme etableres næsten samtidigt og indgår $\mathrm{i}$ den olympiske periodos o. 582 f.v.t. i Delfi, 573 f.v.t. i Nemea og o. 550 f.v.t. i Isthmia. ${ }^{11}$ Artiklen antager et tidsmæssigt sammenfald mellem de tidligste sportslige entreprenørarbejder og afholdelse af disse lege. Blandt mange teorier om de nye fællesgræske festivals opstån fremsætter den amerikanske arkæolog Gebhard det syn, at disse leges reorganisering fra lokale stævner til fællesgræske festivals blev festligholdt som udtryk for et tyranstyres fald og folkets overtagelse af legene med en efterfølgende mytologisering af legenes opkomst. ${ }^{12}$

Det er efter denne sportslige »die Wende $\ll$, at træningsanlægget palæstra senere kommer til at indgå $\mathrm{i}$ en samlet sportslig 
helhed. Hvor fysisk dannelse i den arkaiske og klassiske periode var en udelelig/individuel del af personlighedsudviklingen uden topografisk adskillelse mellem kult og idræt, sker der i hellenismen en synlig afstandtagen - klart markeret i Olympia. Hvor der tidligere var trænet i det fri, blev aktiviteten lukket inde, afgrænset og blev rum for finpudsning af det græske personlighedsideal, kalokagathia, hvor den frie mandlige voksne græske borgers præstationsevne blev stillet til skue i O-D-I-N som rollemodel for en agonal livsform.

\section{Fokus på danske skrifter}

Den klassiske filolog Leo Hjorts $\varnothing$ har i sin bog Olympia fra 1964 i afsnittene Sportsanlag og traning beskrevet og illustreret gymnasion og palæstra i Delfi og Olympia. Bogtitlen indebærer naturligvis, at blikket er rettet mod det markante konkurrencested på Peloponnes med angivelse af rumbetegnelser og funktion for gymnasion og palæstra. ${ }^{13}$ Nationalmuseet udgav i 1972 For sportens skyld, hvori kapitlet Fra kultidrat til sportskult $i$ Grcekenland og Rom nævner de bygningsmæssige rammer for palæstra og gymnasion uden at præcisere form og funktion nøjere..$^{14} \mathrm{I}$ det olympiske år 1980 udgav Sfinx bogen Den grceske Olympiade, som i tredje kapitel, Olympia som sportscentrum, sammenskriver (under delkapitlet, Gymnasion) de foreliggende forskningsresultater med hensyn til form og funktion. Tilsvarende omfang gives samlet de tre $\varnothing$ vrige $»$ panhellenske« konkurrencesteder, hvor de nyeste arkæologiske udgravninger ikke har kunnet medtages, da de er foretaget efter 1980 og i $\varnothing$ vrigt stadig foregår. Året efter fulgte endnu en bog, Den graeske Sport, fra samme forlag, der i tematisk form behandler nogle af sportens relationer. ${ }^{15}$ I en specialeaf- handling fra Odense Universitet, 1990, Det grceske Gymnasion, Funktion og Form analyserer Wien udvalgte gymnasier som hovedbegreb og selvstændigt begreb i træningsanlægget, hvor palæstra forbliver en relation. Danmarks Idræts-Forbund har i år 2000 udgivet hæftet $P \stackrel{a}{ }$ sporet af det olympiske, hvor palæstra og gymnasierne i få linier omtales som træningssted i polis. ${ }^{16}$ I en topografisk plan over hele helligdommen i Olympia indplaceres gymnasion og palæstra, som det forefindes i dag.

Globalt er omfanget af bøger og artikler om de kropskulturelle bygningsmæssige rammer i antikken mere omfattende, hvor hovedværket fra 1960 Gymnasion af franskmanden Delorme påkalder sig berettiget interesse. Af indlysende grunde har han ikke kunnet medtage nyere udgravninger i Nemea og Isthmia. Med særlig afklaring til datering henvises til Mallwitz og til Glass, Wacker og Zschietzschmann med hensyn til identifikation.

\section{Begrebsafklaring}

Ved en etymologisk tilgang til artiklens tema opdages, at palai-s-tra er en substantivistisk orddannelse af $\pi \alpha \lambda \alpha i \omega$ [jeg bryder]. ${ }^{17}$ Palæ s-tra $(\pi \alpha \lambda \alpha i \sigma \tau \rho \alpha)$ er rummet eller stedet for brydning som orche s-tra er stedet for dans. Ordet er også beslægtet med et ord, der betyder den flade hånd, håndens værk, kunstgreb. Brydning kunne således være det værk, arbejde, som den flade hånd udøver, hvilket vises i palæstramotiver på græske vaser fra denne tid.

Begreberne palæstra og gymnasion kan dokumenteres i indskrifter fra slutningen af den arkaiske periode. Bacchylides (ca. 520 f.v.t. - ca. 460 f.v.t.) lovsynger i ode 18.2 Theseus's far, Aigeus, for at han lukkede Kerkyon's palæstra 
»Aegeus [25] tan te Kerkuonos palaistran eschen ... ${ }^{18}$

»Aegeus [25] han lukkede Kerkyon's palaestra."

Myten fortæller, at bryderen Kerkyon bosiddende i Eleusis ombringer vejfarende $\mathrm{i}$ sin palæstra.

I sin »Historie« omtaler Herodot (ca. 485 f.v.t. - ca. 424 f.v.t.) begrebet palæstra i fortællingen om tyrannen i Sikyon, Kleisthenes, der efter sin olympiske sejr i firspand anlægger dels en løbebane (dromos) dels en brydeplads (palaistra) til underholdning for potentielle svigersønner.

»[3] toisi Kleisthenês kai dromon kai palaistrên poiêsamenos ep' autôi toutôi eiche ${ }^{19}$

»... Den store Kleisthenes etablerende selv både løbebane og brydeplads $i$ anledning af.«

Ifølge en konstrueret olympisk sejrsrække sker dette o. 572 f.v.t. ${ }^{20}$ Herodots historie er forfattet omkring midten af det 5 . århundrede f.v.t. og fortæller i en sidebemærkning om den godt 100 år gamle etableringssag. Korinths naboby har således muligvis i midten af det 6 . århundrede haft et sted for atlettræning som forberedelse til deltagelse til Olympia og andre panegyriske lege. Sikkert er det, at Herodot anvender de to begreber - palæstra og gymnasion - hvilket betyder, at de på hans tid er kendte. Dromos som løbebane og palæstra betyder ikke nødvendigvis en institutionaliseret brydeplads med bygninger, men muligvis blot en indhegnet plads i det fri. I så fald er det naturligvis vanskeligt at finde arkæologiske levn herfra.

Platon (427-347 f.v.t.) omtaler i Euthydemos Sokrates' besøg i gymnasiet Lykeion. ${ }^{21}$ Sokrates sidder i afklædningsrummet
"... idôn oun me ho Kleinias apo tês eisodou monon kathêmenon, antikrus iôn parekathezeto ek dexias, ${ }^{22}$ »... Da denne Kleinias så mig siddende fjernt fra indgangen gik han tvars over sattende sig til højre.«

En indgang kan antyde ydre lukkethed. Øjenkontaktmulighed en indre åbenthed, hvor afklædningsrum ikke er placeret ved indgangen. Hverken her eller senere i teksten antydes eksistens af en gård, men dog »katastegos dromos « dvs. overdækket løbebane Da der ikke eksisterer træningsløbebaner med mere uden palæstra, må dette afklædningsrum være i palæstra.

Aischines (o. 390/89 f.v.t. - o. 315 f.v.t.) anvender betegnelsen palæstra i en af sine taler [Kata Timarchou] $]^{23}$

10.[10] ... kai tous didaskalous ta didaskaleia kai tous paidotribas tas palaistras anoigein men apagoreuè̀ mè proteron prin an hêlios anischêi, klêiein de prostattei pro hêliou dedukotos, tas erêmias kai to skotos en plìstề hupopsiai poioumenos: kai tous neaniskous tous eisphôitontas hous tinas dei einai kai has tinas hélikias echontas, kai archén hétis estai hê toutôn epimelêsomenê, kai peri paidagôgôn epimeleias kai peri Mouseiôn en tois didaskaleiois kai peri Hermaiôn en tais palaistrais, kai to teleutaion peri tês sumphoitéseos tôn paidôn kai tôn chorôn tôn kukliôn.«

»10. Den forbyder skolelarere at åbne deres skoler og gymnastiklarere deres palcestrer før solopgang ... regler for, ... deres gang $i$ skole og palcestra, ... og Hermesfesten i palcestrene, samt børnenes samver i skole og palcestra ... $\ll^{24}$ 
Den klassiske filolog, professor Otto Steen Due anfører hertil i en note, at palæstra betyder brydeplads, men i en udvidet betydning sportsplads som et sted for gymnastiklærernes private palæstrer for skoledrenge til forskel for de offentlige brydepladser. I O-D-I-N ledes palæstra af offentlige myndigheder.

I Athens Forfatning fra ca. 360. f.v.t. lægger den gamle oligark en socio- $\varnothing$ konomisk skillelinie mellem gymnasion og palæstra, hvor private rige bygger gymnasier, og folket palæstrer.

»Kai gumnasia kai loutra kai apodutêria tois men plousios estin idai enios, ho de dêmos autos hautôi oikodemeitai idiai palaistras pollas, apodutêria, loutrônas. $\ll^{25}$

»både gymnasier, svømmebade og afkladningsrum ...«

Et første beskedent indtryk af palæstra fra den klassiske periode tegner et billede af en bymæssig bebyggelse, der vender ryggen til og skærmer af for nysgerrige blikke, gør en lukning af uddannelsesstedet mulig og retter sin opmærksomhed mod stedets kærne for dokumenterede træningsaktiviteter som brydning, boksning og pankration.

Lidt større kendskab fås gennem en senere rejsebeskrivelse. Den græske omrejsende geograf Pausanias påpeger omkring midten af den 2. århundrede e.v.t. i sin guide, Grakenlandsbeskrivelse, eksistensen af såvel palæstra som gymnasion i eksempelvis Olympia, Delfi og Elis. Han nævner Isthmia, men uden at omtale gymnasion eller palæstra. Enten har institutionerne aldrig eksisteret, blevet destrueret af den romerske hærfører Mummius i forbindelse med Korinth's ødelæggelse eller også har de været uden betydning. Nemea omtales ikke. I hans bog VI kap. 23.1-7 omtales tre gymnasier af forskellig alder i Elis, hvoraf det ene aflukkede har en firkantet form, hvor der praktiseres brydning og boksning.

»... gymnasou peribolos tetragônon de onomazousìn epi tôi schêmati; ... kai palaistrai tois athlosiv entautha poiouvtai. $\ll^{26}$

»... gymnasiets omsluttende mur ... som kaldet kvadratisk efter sin form ... og palastrer blev her brugt af atleterne til.»

Hvor det først beskrevne er det gamle gymnasion med den overdækkede løbebane og den åbne parallelbane, paradromis, er der her tale om palæstra - trods lidt begrebsmæssig uklarhed $\mathrm{i}$ hans beretning. Pausanias indleder i bog VI sin beskrivelse af det andet, egentlige palæstraanlæg i Elis med påbuddet om, at atleterne træner her forud for konkurrencen i Olympia.

Ved en tabelopstilling ud fra Perseus Collections, angående hvor hyppigt henholdsvis palæstra og gymnasion optræder hos forfattere fra den senarkaiske, klassiske, hellenistiske og tidligere romerske kejsertid, er det vanskeligt direkte at påpege en begrundet forskel i begreberne gymnasion og palæstra.

Begge begreber optræder i den tidlige klassiske periode, men i beskedent omfang og anvendes hos mange forfattere i flæng. Vel optræder gymnasion langt hyppigere i den klassiske periode, men det skyldes primært Platon's og Xenophon's markante brug af ordet gymnasion, selvom begge også anvender palæstra. Aischines anvender ligeligt begge begreber. Lykeions leder, Aristoteles, bruger slet ikke begrebet palæstra, hvorimod hans efterfølger Theophrastus kun anvender palæstra om dannelsesstederne i polis. Man kommer ikke nærmere en afklaring ved nøjere at analysere 
Tabel 1: Ordhyppigheden af: palaestra og gymnasion i graesk og romersk materiale

\begin{tabular}{|c|c|c|c|c|}
\hline forfattere & fødselsår & dødsår & palæstra & gymnasion \\
\hline Bacchylides & -520 & -460 & 1 & \\
\hline Herodot & -480 & -420 & 5 & 2 \\
\hline Antifon & -490 & -411 & & 2 \\
\hline Euripides & -485 & -406 & 2 & 4 \\
\hline Andocides & -440 & -390 & & 2 \\
\hline Aristofanes & -450 & -385 & 6 & 4 \\
\hline Den gamle Oligark & -425 & -354 & 1 & 1 \\
\hline Xenophon & -425 & -354 & 1 & 21 \\
\hline Platon & -427 & -347 & 9 & 39 \\
\hline Isocrates & -436 & -338 & & 7 \\
\hline Hypereides & -399 & -322 & 1 & \\
\hline Aischines & -390 & -322 & 5 & 6 \\
\hline Aristoteles & -384 & -322 & & 8 \\
\hline Demosthenes & -384 & -322 & & 2 \\
\hline Theofrast & -372 & -289 & 3 & 1 \\
\hline Theokrit & -310 & -250 & 9 & 1 \\
\hline Diodorus & & 1 & & 5 \\
\hline Vitruvius & -70 & 014 & 1 & \\
\hline Pausanias & -14 & 024 & 6 & 53 \\
\hline Strabo & -65 & 028 & & 14 \\
\hline Flavius Josephus & 37 & 100 & & 4 \\
\hline Appian & & 110 & & 11 \\
\hline Plutarch & 45 & 120 & 3 & 5 \\
\hline
\end{tabular}

www.Perseus.tufts.edu

den sammenhæng, hvori ovenstående antikke forfattere bruger henholdsvis det ene eller det andet. Et juridisk kriterium kan ikke adskille de to begreber $\mathrm{i}$ et privat eller offentligt regi. Børn og voksne kommer lige gerne begge steder. En tidsmæsssig udvikling, hvor palæstra skulle være det oprindelige begreb, kan fra samme materiale ikke konstateres, hvor de ældste er forfattet i slutningen af den arkaiske periode, og de yngste, der her er medtaget, er fra begyndelsen af den romerske kejsertid. ${ }^{27}$ Der er næppe tvivl om, at det overvejende var voksne atleter, der anvendte palæstra i Olympia og Delfi.
Der pågår i dag en omfattende diskussion i forsøget på at adskille eller sammenlægge de to begreber palæstra og gymnasion. Den kan sammenfattes i teorien om et »Gesamtanlage«, hvor gymnasion er fællesbetegnelse for hele træningsanlægget eller opfattelsen af, at gymnasion alene er et parklignende træningsområde med løbebaner uden for den ofte næsten kvadratiske bygning palæstra. Hvis brugerne dengang skelnede, er kriterier herfor vanskelige at opstille. I denne artikel opfattes de adskilt (jf. afsnittet Palcestra er:) 


\section{Vitruvius}

Det er imidlertid først med den romerske militær- og civilingeniør, Vitruvius Pallio, at palæstra beskrives nøjere. Originalmanuskriptet eksisterer næppe. Den ældste bevarede beskrivelse stammer fra Harleian-manuskriptet fra det 8 . århundrede e.v.t. ${ }^{28}$ I De Architectura libri decem i X bøger o. 30 f.v.t. - 20 f.v.t. beskriver Vitruvius en række apparater og bygningskonstruktioner - herunder et træningsanlæg i V. bog kap. 11.1-4. Den latinske tekst er uden titel og tegning, men omhandler $" p a$ laestrarum aedificationes«.

»... In palaestris peristylia quadrata sive oblonga ita sint facienda, ut duorum stadiorum habent ambulationis circutionem, quod Graeci vocent diaulon ..."

»... I palaestrer er en kvadratisk eller aflang åben plads omgivet af søjler på denne måde, som grakerne kalder diaulo."

Palæstra identificeres som en firkantet søjleomkranset plads. Vitruvius fortsætter beskrivelsen med, at denne plads på alle fire sider er omgivet af en række rum med specifikke formål, samt at palæstra yderligere har den overdækkede løbebane, xystos, den åbne parallelbane, paradromis, og antyder en mulig placering af et sportsanlæg med tilskuerpladser bag xystos..$^{29}$ Der er kun fundet og frilagt få palæstrafundamenter, og enkelte heraf svarer til denne idealtype, mens hovedparten varierer såvel i orientering, form som indretning. Dette har vanskeliggjort identifikation, især da flere lokale forhold som mål og terræn kan betinge større afvigelse fra Vitruvius's idealtype. Hans kendskab stammer fra et sandsynligt bes $\varnothing \mathrm{g} i$ det græske hovedland og de vestgræske byer i Lilleasien. ${ }^{30}$ Der har muligvis været tegninger efter hver bog, men de er ikke be- varet. Plantegninger er således altid rekonstruktioner på grundlag af disse beskrivelser og frilagte antikke bygningsrester.

\section{Palæstra er:}

Kernen i palæstra er den meningsbærende gårdsplads. Tagdækkede rum, som kun er åbne mod denne, gør de fysiske træningsmuligheder mindre vejrafhængige og giver ly og læ for intellektuelle muligheder i samtale og diskussion. Den fysiske som intellektuelle dannelse kræver rum for afklædning, bad, depot med mere, hvilket nødvendigg ør, at kernepladsen kan være omgivet af facilitetsrum på alle fire sider, men dette er ikke normen. De arkæologiske fundamentrester viser her afvigende grundplaner. Palæstra i Milet har kun en enkelt fløj, i Delos to fløje, mens palæstra i Epidaurus og Olympia fremviser en næsten kvadratisk bygning, hvor brydepladsen er helt rumomsluttet. Hvor fristende det end er, er det ikke her opgaven at give et samlet billede af de bygningsmæssige principper for grundplanerne. Der er næppe tvivl om, at terrænmæssige forhold og deraf afledte bygningsmæssige vanskeligheder har måttet influere på placering og orientering af en palæstra. Adækvat vandtilførsel og ly for den brændende sol har været en fælles betingelse, mens læ for vinden kan være lokalt betinget og dermed gjort orientering og form forskellig.

Stadion og fod er her anvendt som en antik længdebetegnelse. I beskrivelsen af stedet for træning anvendes træningsanlæg omfattende palæstra/gymnasion, overdækkede som åbne løbebaner (xystos \& paradromis), badeanlæg med svømmebassin (loutron) eller plumpebassin, mens selve konkurrencestedet med tilskuerpladser (teathron) $\mathrm{i}$ artiklen betegnes som sportsanlæg. 


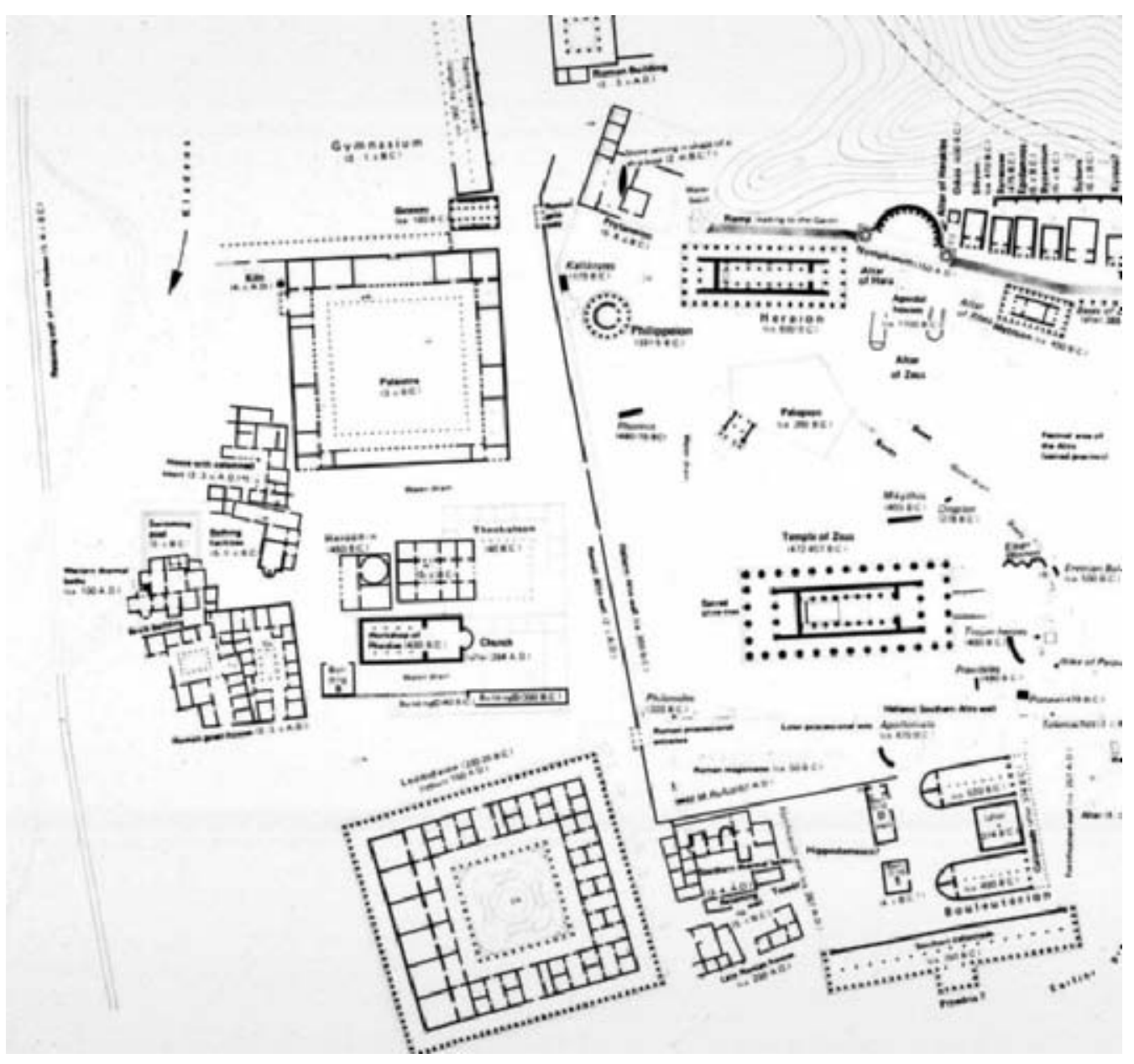

Figur 3: Topografisk plan over vestlige del af Olympia (Deutsche Arcäologische Institut).

\section{Olympia}

Olympiahelligdommen ligger, hvor den største flod på Peloponnes, Alpheios, får tilløb fra bifloden Kladeos. Det flade flodleje vanskeliggør ikke i større omfang etableringen af arealmæssige store sportsanlæg. Træningsanlægget med palæstra ligger vest for det muromkransede hellige område, Altis, mod Kladeos. I slutningen af det 19. århundrede e.v.t. graver tyske arkæologer systematisk ud og figur 3 er hentet fra offentliggørelser i $1898 .{ }^{31}$ Allerede i
1884 påbegyndte det græske arkæologiske selskab udgravninger af det nordvestlige palæstra. ${ }^{32}$

Palæstra fremtræder så velbevaret hel med godt én meter høje og tykke kvaderstens yder- som indermure og genrejste søjler, at den besøgende får et godt indtryk af et meget stort, symmetrisk anlægs omfang. Bygningens fire sider er orienteret som verdenshjørnerne med samme linieføring som Heroon (6. årh. f.v.t.), Theokoleon (4. årh. f.v.t.), Fidias's værksted (o. 430 f.v.t.) og Zeustemplet (468-456 f.v.t.) 
- stedets hovedgud (se figur 3). Besøgende og pilgrimme er kommet vestfra ad den hellige vej fra Elis via Alpheios-flodlejet til helligdommen og har haft træningsan- lægget på venstre hånd, inden den hellige lund er betrådt.

Fra palæstra stiger terrænet let til et 0,74 $\mathrm{m}$ højere niveau, hvor gymnasion ligger.

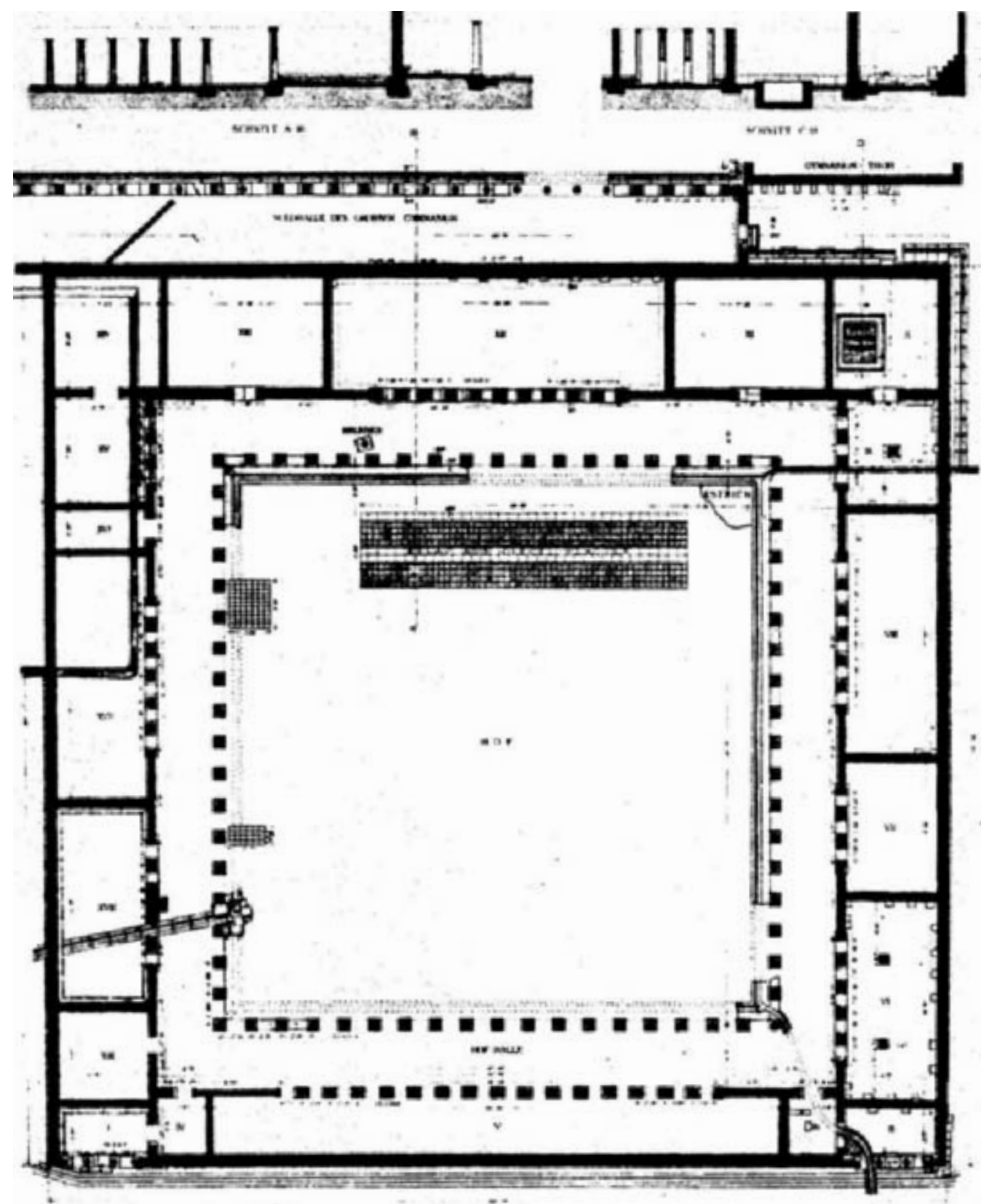

Figur 4: Grundplan af palcestra i Olympia (Curtius \& Adler) 
Vand herfra vil således ved egen hjælp kunne løbe ned til palæstra.

Palæstra's kerne på 41,42 x 41,56 m er en kvadratisk brydeplads af stampet sandblandet jord. Denne er omgivet af 72 doriske søjler - en peristyl. ${ }^{33}$ En rillet teglstensflade på 24,2 x 5,4 m i pladsens nordlige del afviger fra gårdspladsen jord og sandstampede flade og har givet anledning til adskillige gisninger i forsøget på identifikation. De genrejste slanke doriske søjler, der kun skulle bære peristylgangens træloft, består af to tromler af lidt forskellig længde med 20 kannelurer (se figur 1, hvor disse doriske søjler er gengivet). Den side i nederste tromle, der vender mod den kun 4,75 m overalt lige dybe peristylgang, er afrundet en mulig funktionalitet i denne vandre- og løbegang. Søjlerne er lavet af områdets sten, muslingekalk. Afstanden mellem to søjleakser, interaksialrummet, i den indre søjlerække er 2,30 m og nedre søjlediameter er $0,566 \mathrm{~m}$, svarende til 4,06, det vil sige, at der kunne placeres godt fire søjler i interaksialrummet og i modsætning til det klassiske doriske Zeustempels noget tungere 2,3. Sættes søjlediameteren i relation til højden fås forholdet 1:6,7. ${ }^{34}$ Zeustemplet udviser da et 1:5,9-forhold. Det lettere palæstratag behøver færre søjler pr. løbende meter, men søjler med samme relative dimension. Der er mellem søjle fem og seks i peristylgangens nordvestlige del fundet en brønd, som på grund af placeringen må have eksisteret før opførelsen af palæstra. Adskillige brønde er registreret og frilagt uden for Altis. Antallet aftager i takt med forbedret kanaliseret vandforsyning. Der er fundet en brønd i det lille rum XVI, som har sikret bygningen vand, og den er givet vis udgravet i forbindelse med opførelsen, idet Kladeos-flodens ringe vandmængde om sommeren og lavere vandspejl næppe har kunnet give en optimal vandforsyning. Det viser sig da også, at man med forbedret teknologi senere fører vand gennem rør fra fjerne kilder i stedet for at hente det i floden. Om rum XV alene har været et mellemrum fra peristylgangen til det egentlige baderum XIV, der givet vis også har fået tilført vand udefra gennem den stadig synlige åbne vandledning, hvis orientering er mod gymnasiepladsen, hvor en nu lukket brønd har været, vides ikke. Muligvis har såvel rum XV og XIV været vådrum. Faktum er, at med en nordlig indgang for vand har dette af egen kraft kunnet strømme nedad mod de sydligere dele af bygningen. En åben udhugget vandledning langs søjleindersiderne har kunnet opsamle tagregnvand samt lede indført vand fra rum IX til atleterne. Afløb finder sted via rum XVIII. Rum IX \& X har muligvis erstattet baderummet i XIV \& XV, hvor badekarret i rum $\mathrm{X}$ er lavet i den romerske periode. Syd for palæstra er afdækket badehuse og et svømmebassin på ca. $16 \times 24$ meter fra midten af det 5. århundrede f.v.t. ${ }^{35}$ Atleterne har ikke skullet $»$ gå over gaden efter vand «.

Palæstra har 19 rum, hvor kun de fire hjørnerum savner direkte forbindelse til peristylgården. Som ses på figur 4 åbner de $\varnothing$ vrige sig enten med joniske søjler - alle med varieret kapitæl - in antis eller har almindelige døråbning, hvor en enkelt muligvis har kunnet aflåses (XIX). Plantegningens nordlige og sydlige fløj viser en form for symmetri om brydepladsen med åbne rum centralt. For en besøgende træder rum XII markant frem med en dybde, der er synligt større end rummene i de tre andre fløje. Det nordlige dybe centrale rums længde er tre gange bredden med en indre kolonnade af ni joniske søjler. Den vestlige og østlige fløj fremtræder umiddelbart symmetrisk med åbne rum med søjler og samme rumdybde, men modsvares ikke i antal og dermed størrelse, hvilket kunne 
pege på forskellige funktioner. Fra peristylets sydside åbner 15 joniske søjler til et langstrakt rum (V), der sammen med de to symmetrisk anbragte indgange »synssluser« (I og II) danner bygningens sydside. Betegnelsen »sluse« er anvendt her, idet den udefrakommende / uvedkommende ikke umiddelbart kan se til aktiviteterne. En del rum har stenbænke langs væggene. Få rum har flisegulv. Al lys kommer fra den åbne indre gård, idet der ikke har været lysåbninger i palæstras ydre væg.

Som monumentet fremtræder i dag, kan iagttages et par bygningsmæssige ændringer. Der er foretaget et murgennembrud i rum XII. Ændringen er sket i forbindelse med etableringen af det af Pausanias benævnte gymnasion. Herved åbnes for adgang til rækken af faciliteter i palæstra. Udvidelsen af træningsanlægget har samtidigt betydet, at den stadig synlige nordøstorienterende vandledning til og fra rum XIV har måttet afbrydes. En muligvis afledt samtidig ændring ses i rum XV, hvor der er påsat en stilmæssig afvigende vestlig indgang. Denne portal med fire doriske søjler stammer muligvis fra andet byggeri i Olympia.

\section{Datering}

Palæstra-monumentet, som det fremtræder, hviler ikke på tidligere byggeri. Jordstykket antages at have været udlagt som træningsplads i dens nærhed af flod og badehuse fra det 5. århundrede f.v.t. og forsynet med brønde. Der er ikke fundet byggeregnskaber, ingen bygmester eller bygherre er omtalt, hvorfor en datering må ske ud fra anvendte byggematerialer og byggestil og i relation til mulige absolutte dateringer af andre bygninger. Midt i det 4. århundrede f.v.t. påbegyndes større profane byggeaktiviteter med blandt andet en græsk mur.
Denne ældste mur omkring Altis giver adgang til træningsområdet via en port nord for Philippeion. Muren er således yngre end denne, der er opført af Aleksander den Store o. 330 f.v.t. Hvis palæstra har eksisteret før den tid, er det tænkeligt, at der da ville have været direkte forbindelse mellem Altis og palæstra's sydlige indgange en forbindelse, som er blevet etableret ved den efterfølgende romerske mur. Forsigtigt kan indledningsvis antages, at palæstra må være opført efter 330 f.v.t. Sporten lukkes på dette tidspunkt ude fra Altis. Den kultiske forbindelse svækkes.

Olympia er præget af dorisk stildominans. Det kommer tydeligt til udtryk ved tempelbyggeri i forbindelse med opførelsen af templet Metroon o. 320 f.v.t. Den joniske ordens fremtrængen sker primært inden for profant byggeri og skaber en $\gg$ mixed order« som i eksempelvis stoaen. Her ses de længere joniske søjler som bærere af tagbjælken, og derved løfter de huset. $^{36}$ Det samme er tilfældet med palæstra. Peristylgårdens doriske søjler udviser i nogle få søjlemål klare doriske udviklingstræk. De mere dekorative joniske indre søjler er i overensstemmelse med den yngre klassiske periodes kanon. De stærkt dekorative korinthiske søjler har vist sig ikke at være anvendt i palæstra; men tiden har været moden, idet denne orden har fundet anvendelse i sydhallens indre søjler fra o. 333 f.v.t. Den prægtige hovedindgang til hele træningsanlægget har ydre korinthiske søjler, dateret til slutningen af det 2. århundrede f.v.t. ${ }^{37}$ Stilmæssigt afviger palæstra ikke fra senklassicismens doriske norm og må anses for at være ældre end gymnasion, hvilket yderligere ses gennem bygningsændringen i rum XII, de tydelige fundamentsten for gymnasions sydhal mod vest, der flugter med palæstra's fornyelse mod nord, og den lidt skæve vinkel, gymnasion 
møder palæstra med. Genbrugsportalen ved rum XV er derfor uinteressant for datering af palæstras opførelse. Stilmæssigt peger opførelsen af palæstra således på afslutningen af den klassiske periode.

Stadionlængden på de 600 fod i det klassiske sportsanlæg III i Olympia er 192,27 $\mathrm{m}$ svarende til en dorisk/pheidonisk fod på $0,3205 \mathrm{~m} \cdot{ }^{38}$ Samme fod synes også anvendt ved udlægningen af den søjleunderstøttende flade på Zeustemplet - en såkaldt stylobatflade på 90 x 200 doriske fod og et udtryk for den kanoniserede doriske orden. Antages det, at peristylgården i palæstra ved opførelsen er udlagt først, det vil sige, at byggeriet er påbegyndt indefra, og antages det endvidere, at den dorisk/pheidoniske har været kanon, så ville den først udlagte stylobatflade for palæstra have en »umage« 129,23 fod. Dette kunne være tilfældet, men uden for streng dorisk orden. Antages derimod, at der er anvendt en hellenistisk fodlængde på $0,301 \mathrm{~m}$ fås en sidelængde på 138 hellenistiske fod og et interaksialt rum på 72/3 fod. ${ }^{39}$ Arkæologen Dinsmoor angiver et mål på 135 fod. ${ }^{40}$ Dette svarer til en hellenistisk fodlængde på 0,307 m. Vigtigst her er, at doriske målenheder er forladt. Med udgangspunkt i anvendelse af hellenistisk fod har peristylgården en dybde på 152/3 fod. Den ydre bygningskrop vil dække et areal på $221 \mathrm{x}$ 221 fod. Med disse ikke helt sammenfaldende ledetråde for en absolut datering og med den forsigtighed, metrologien altid bør mødes med, fås den tanke, at palæstra muligvis er på vej væk fra stedets doriske dominans og muligvis er influeret af en hellenistisk bygherres ideer. ${ }^{41}$ Ovenstående betyder et opførelsestidspunkt i sidste fjerdedel af det 4 århundrede f.v.t, hvilket ikke er så tidligt som Curtius anfører i note 39 . Hjortsøs kort over Olympia i 300-tallet f.v.t. indikerer en palæstraopførelse senere end den græske mur, Metroon, Ekkohal, det store sportsanlæg, Leonidaion og Sydstoa, idet denne del af træningsanlægget ikke er medtaget. ${ }^{42}$

\section{Identifikation}

Rummenes åbenhed har dengang signaleret, hvilken funktion de hver især havde. Dette signal mangler $\mathrm{i}$ dag. Ingen ved præcist, hvad der er foregået hvor. Vitruvius' funktionsbeskrivelse, en række palæstramotiver på samtidige vaser samt kendskab til sportsdiscipliner gennem sejrslister står til rådighed ved en funktionsbestemmelse. De øst- og vestvendte fløje med rumbegrænsende siddemulighed er næppe optimale for sportstræning, men fremmer stillesiddende samtale, hvorfor disse rum må antages at styrke det intellektuelle liv eller muligvis kultlivet. Ethvert gymnasion/palæstra har en hero, der bivåner træningen. Oftest er disse statuer placeret tæt ved indgangen, hvorfor enten rum VI eller XVIII kan have været sæde for stedets hero. Sokrates' føromtalte be$s ø g$ i Lykeion eksemplificerer, at et afklædningsrum kan ligge skråt og fjernt for indgangen. Med kort afstand til badet kan det store markante rum XII med bænke være det sted, hvor atleter indleder og afslutter deres træning og derfor også det sikre samtalested for filosoffer og læreres omgang med de kropsduelige. At det ved ombygningen bliver bindeled mellem gymnasion og palæstra svækker ikke denne antagelse. Hermed demonteres flere forskeres opfattelse af, at rum XII alene er den store forelæsningssal, ephebeion, som Vitruvius' senere dimensionsangivelser af længde/breddeforholdet som 3:1 passer på. ${ }^{43}$ De to naborums dimension, lukkethed og et beskedent lysindfald har næppe kunne tjene som træningslokale endsige stimu- 
lere til samtale, men snarere været magasin for olie og sand, som er nødvendige ingredienser for sportsudøvelsen. Bademulighederne placeres i hvert nordlig højereliggende hjørne. Det langstrakte, meget åbne sydrum må være et sportsrum, hvor spring$\emptyset$ velser har kunnet finde sted, når vejret ikke tillod træning i det fri, og hvor springvægte (halters) næppe har forvoldt skade ved deres bagudkast. De udvidede adgangsforhold, hvor de olympiske atleter, trænere og dommere benytter den vestlige indgang nær en formodet senere opført atletbeboelse, har kunnet betyde, at de to oprindelige sydlige indgange har været til den græker, der i en periode af sit liv frekventerer helligdommen. Hvis træningsanlægget har haft en gymnasiark, som bl.a. kendes fra Eretria, kan denne have resideret i rum XIX ${ }^{44}$ Det har ved sin placering tæt ved indgangen muligvis fungeret som rum for gymnasiarken og har sandsynligvis kunnet aflåses.

Olympia er ikke en bystat. Afstanden til den i lange perioder styrende polis, Elis, med egne gymnasier og palæstrer har betydet, at Olympias træningsanlæg næppe har haft denne lille bystats mandlige befolkning som kundegrundlag og må have haft en anden funktion end eksempelvis Platons akademi eller Aristoteles' Lykeion. Det har ikke kunnet fylde i et byhverdagsliv

Forskningslitteraturen stiller sig i dag uforstående over for det tilsyneladende voldsomme misforhold mellem palæstras kapacitet og udnyttelsesgrad. Hvad betinger et så fornemt anlæg med fem til seks ugers brug hvert fjerde år? Den fjerne beliggenhed fra nogen bystat udelukker bystatsborgerens hverdagsbrug. Funktion som et kaserneanlæg for en stående hær synes usandsynlig. Bystaten Elis havde behændigt undgået nogen alliance vendt mod tidens stærkeste magtcentrum - makedo- nerkongen. Ja, Olympia tildeles den ære at lægge grund for det makedonske dynastis rundbygning, Philippeion. Pilgrimme og »turister« har her kunnet træne og udvikle det græske personlighedsideal; men i hvilken grad dette har været tilfældet, savnes der belæg for. Med samme smalle dokumentationsafsæt er palæstra/gymnasion også blevet betegnet som »et antikt kulturcenter «, hvortil omvandrende eksperter filosoffer, retorikere etc. - valfartede. ${ }^{45}$ Hellenismens stigende $\varnothing$ nske om at opføre monumentalbygninger, hvilket kunne afspejles i de næsten samtidige Ekkohallen, Sydstoaen og Leonidaion, antyder samme hang til grandiositet, men tilsyneladende genfindes samme tendens imidlertid ikke ved de tre andre festivalsteder - Delfi, Isthmia og Nemea. Olympia's status har altid været og er fortsat måske i den grad så særegen, at det berettiger til denne store investering, som må have givet mæcen og festival stort omdømme.

\section{Delfi}

I den meget bjergrige egn i Fokis, med Parnassosbjergets klippeudløber, Fædriderne, som nordlig væg, er træningsanlægget i Delfi placeret med palæstra, plumpebassin og løbebaner. Apollons helligdom ligger mellem dette og konkurrenceanlægget. Terrænforhold giver én forklaring, men ikke nødvendigvis den rette. Sport og helligdom adskilles her ved naturlige grænser. Højdekurverne i figur 5 viser de vanskelige terrænforhold for etablering af større sportsanlæg.

Pausanias stedfæster yderligere træningsanlægget ved

»... Hvis man fra gymnasiet drejer mod venstre nedad sådan ca. tre stadier, som kommer man til floden ved navn Plei- 


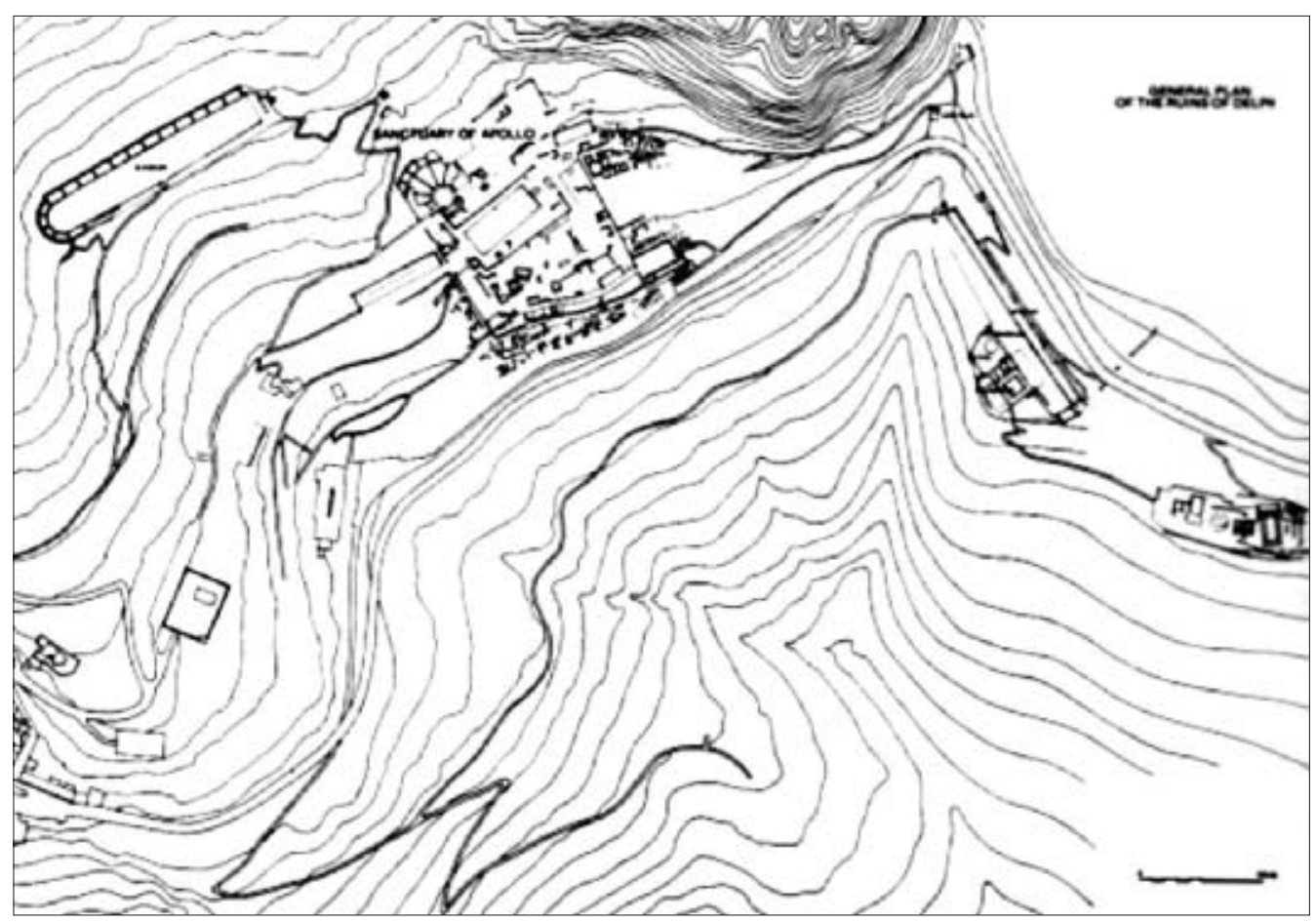

Figur 5: Højdekurvekort over Delfihelligdommen (Tzachou-Alexandri).

stos. Den lober ud $i$ havet ved Delfis havn, Kirrha ...«

»... Hvis man går opad fra gymnasiet [gumnasíou] til helligdommen, ligger Kastalias vand på højresiden af vejen ... $\ll^{46}$

Noget af det første, arkæologer i 1898 stødte på, var palæstra, som dannede basis for en byzantinsk klosterkirke. ${ }^{47}$ Ved dens nedrivning er kun antydningsvise grundsten af palæstra blevet tilbage. De meget vanskelige byggeforhold har betydet, at træningsanlægget er anlagt på to terrasser, hvoraf den $\emptyset$ verste har en længde på ca. 200 meter, den nedre fem-kantede på ca. 60 meter som led i en samlet byggeplan med to parallelle orienteringsakser nord$\emptyset$ st-sydvest, som er præcis vinkelret på Apollontemplets $\emptyset$ st-vestakse. Palæstra ligger ikke som i Olympia i forlængelse af løbebanerne.

På figur 6 er det muligt i anlæggets sydvestlige hjørne at se konturerne af det kvadratiske bygningskompleks. Nord herfor i samme niveau ses det runde plumpebassin. Til venstre på den $\emptyset$ vre terrasse anes dele af løbebanerne. Der er i dag nedfældet tynde trælister for at markere palæstras mure. Let grus mellem disse beskytter den underliggende oprindelige lokale blå-grå kalksten.

Palæstra ses som den nederste vestlige del af anlægget, og selvom der kun resterer en del af fundamentet, ses en ydre form svarende til Olympias kvadratiske, blot betydeligt mindre. ${ }^{48}$ De fysiske forhold i dag viser en terræntilpasning med jord og klippeopfyld. Bystaten Delphois beboere har langs det kastaliske vandløb været inden for gåafstand til træningsanlægget, pil- 
grimme enten fra $\emptyset$ st, fra stedets havneby ved den korinthiske bugt eller fra nordvest har med fordel kunnet vælge den sydlige indgang $\mathrm{H}$. To trapper har forbundet de to terrasser. Hvor atleterne har boet under forberedelserne til de pythiske lege vides ikke. Hippodromen er endnu ikke lokaliseret.

Den kvadratiske brydeplads, R, er en peristylgård omgivet af en fire $\mathrm{m}$ lige dyb peristylgang på alle fire sider. Peristylgården måler 13,87 m. svarende til 47 jonisk-attiske fod og er omgivet af en søjlerække i jonisk orden i veludført kalk. Her bemærkes et ukanonisk antal kannelurer på $20 \mathrm{mod}$ de forventede 24 på joniske søjler. Hver side har syv søjler og dermed seks søjlemellemrum på en sådan måde, at der ikke er disharmoni med åbningerne til rum $\mathrm{A}$ og B. ${ }^{49}$ Palæstras ydreform synes dimensioneret med sider af 100 attiske fod. Det er et lille træningsanlæg med en to-fløjet palæstra. Der er kun værelsesfløje mod nord og vest med direkte adgang til kamppladsen, idet den $\varnothing$ stlige søjlegang forbinder sig til støttemuren, analemma I fra den $\varnothing v$ re terrasse, mens den sydlige søjlerække

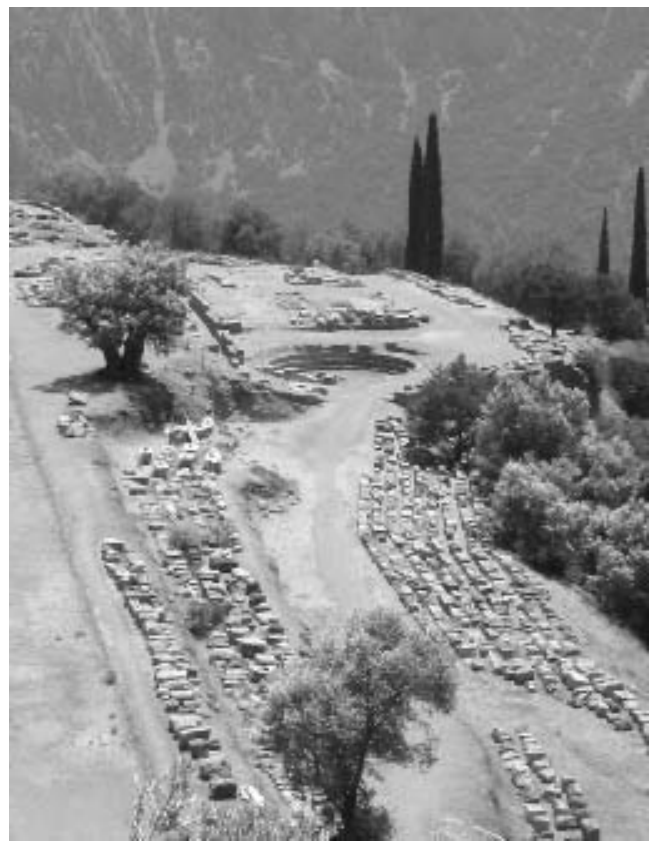

Figur 6: Palcestra til højre med loutron foran. Paradromis til venstre. Foto taget fra nord.

læner sig mod en mur, der støtter en trappe til $\varnothing$ verste terrasse med xystos og paradromis. Den nedre terrasses nordlige del er

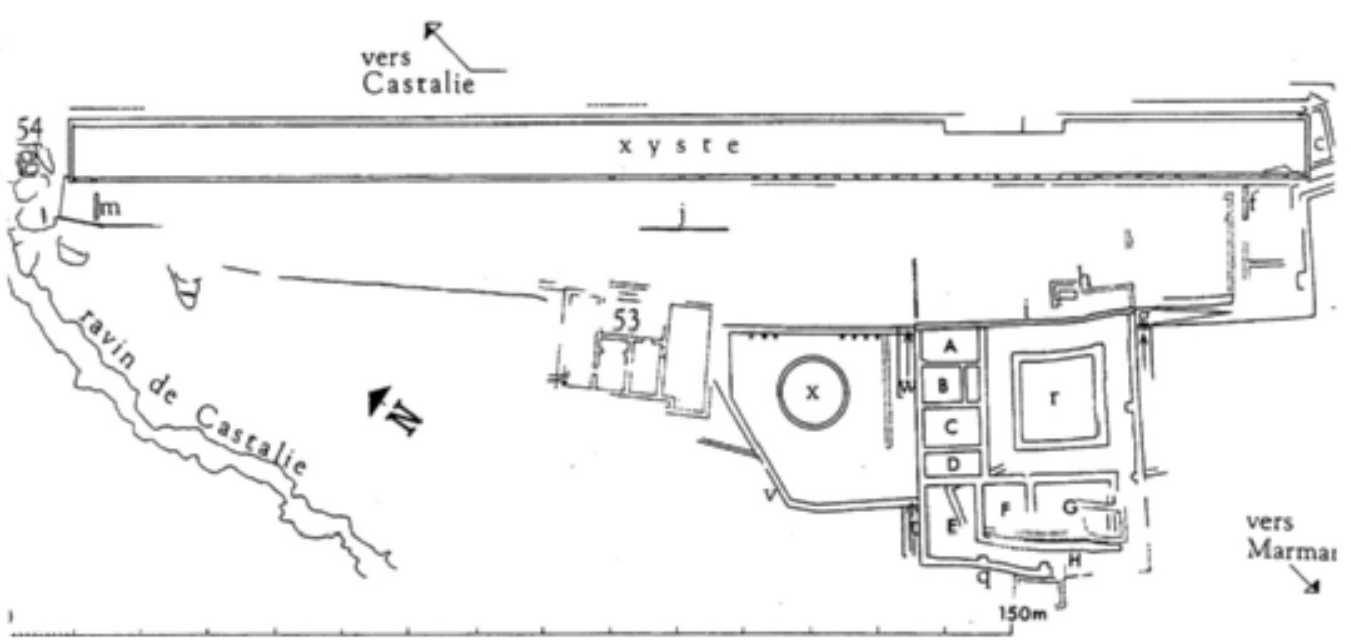

Figur 7: Rekonstrueret grundplan af traningsanlagget i Delfi (Bommelaer). 
grund for plumpebassin og ydre brusebade. Vand fra den kastaliske kilde mod nord er ført i stenrender $\emptyset$ verst på støttemuren og kanaliseres dels til åbne brusere og kummer i støttemuren, dels til loutron og til palæstra.

Der er lokaliseret syv rum, hvoraf det ene, $D$ er en mellemgang mellem peristylgård og bad. De tre nordlige, A-B-C har hver samme størrelse $\left(46,4 \mathrm{~m}^{2}\right)$ med en dybde, som er den dobbelte af peristylgangen, hvilket giver grundplanen et harmonisk udtryk. Da den lille peristylgård kun har kunnet lade en beskeden lysmængde slippe ned, er det muligt, at de enkelte smalle rum i de to fløje har været åbne, men dog uden foranstillede søjler -måske især rum $\mathrm{B}$, hvor en tværvæg har skabt et lille forrum. De tre vestlige, E-F-G har de uregelmæssige størrelser $\quad(74,8 ; 74,9$; $123,05 \mathrm{~m}^{2}$ ), som terrænet nu giver plads for, men afviger ikke mere, end at palæstras ydre form bevares som kvadratisk.

\section{Datering}

I peristylets/peristylgårdens sydøstlige hjørne er fundet dette tegn: $\odot$

Symbolet optræder ligeledes på Apollontemplet, der blev genopført over en længere periode $i$ årene efter naturens destruktion af templet i 373 f.v.t. ${ }^{50}$ Der er givet vis tale om entreprenørens signatur. En vis samhørighed mellem de to byggerier kan hermed formodes. Apollontemplet står færdig i 330 f.v.t.. Regnskaber viser, at bygherren, amfiktyoniet, har søgt penge til opførelsen.

Lige overfor peristylet er på en stenblok fundet navnet $\mathrm{AI} \square$ som højst sandsynligt modsvarer en navnesignatur, $\Delta \mathrm{AI}$, på Apollontemplet. Denne signatur tilhører givetvis også den omtalte entreprenør, der altså har været indblandet i konstruktionen af såvel Apollontempel som træningsanlæg.

I byggeregnskabet for træningsanlægget i 338 f.v.t. står

$» \tau 01 \varsigma \delta \varepsilon \tau[\eta] \varsigma$

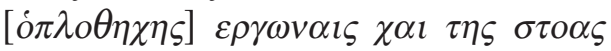
$\tau \eta \varsigma \varepsilon \pi i \tau \omega \imath[\gamma \nu \mu \nu \alpha \sigma \iota \omega]$

[gumnasiw] $\mathrm{i} \ll^{51}$

»men som sagt disse våbenhusets og stoaens kontrakter for gymnasiet«

Med baggrund i ovenstående antages et opførelsestidspunkt for træningsanlægget før hovedtemplets færdiggørelse. Formodentlig er træningsanlægget blevet til i sidste kvartal af det 4 århundrede f.v.t.

\section{Identifikation}

De enkelte rums identifikation er som følge af monumentets ringe tilstand yderst problematisk. Der eksisterer en indskrift, hvor archonten Dion II, det vil sige den for et bestemt år hovedansvarlige embedsmand, omtaler bestemte rum i gymnasiet. ${ }^{52}$ Dette archontår falder i perioden 260 f.v.t.250 f.v.t. Muligvis mere præcist 258 f.v.t., som var et år, hvor pythiske lege fandt sted. ${ }^{53}$ Dionindskriften omtaler et afklædningsrum, (apodyterion), et støvrum, (kônima), et boldrum (sfæristeria) og et rum for olieindsmøring (aleipterion). De ikke pladskrævende, men nødvendige magasinrum for støv/sand og olie kan muligvis placeres i rum A og C. Begge har et areal på ca. $70 \%$ af tilsvarende identificerede rum i Olympia. Næppe nogen af dem har kunnet indfri et sportsligt krav om rum for træning. B-rummet med dets specielle opbygning kunne tænkes at være kultrummet med plads for stedets skytsgud. Loutron og tilstødende brusebade har udgjort træningsanlæggets ydre baderum. 
Afklædningsrummet kan efter en nutidig, rationel betragtning være rum E, idet det ligger centralt for mellemgangen med adgang til $\varnothing$ verste terrasse, bad og peristylgård; men ingen bænke er fundet, hvorfor overbevisende dokumentation herfor mangler. Størst er rum G, som kunne være et exedra. Palæstra/gymnasion har været ledet af en gymnasiark, som dog næppe har kunnet okkupere et lokale i det beskedne træningsanlæg. Byens nærhed har måttet kompensere herfor. Dionindskriftens hele sandfærdighed kan betvivles som følge af identifikation af et boldrum. Boldaktivitet var et yndet sportsmotiv på samtidige vaser, men indgik ikke i rækken af sportsdiscipliner ved de stefaniske lege. Det udelukker ikke boldspil som led i indledende aktivitet før den egentlige hovedaktivitet, men det synes tvivlsomt at spil til bold skulle optage ét rum ud af meget få.

\section{Isthmia}

I bystaten Korinth og $13 \mathrm{~km} \emptyset \mathrm{st}$ for den antikke by på den smalle landtange mellem Peloponnes og Mellemgrækenland og meget tæt ved den Saroniske bugt, hvor den antikke kørevej fra nord til syd går, ligger Isthmia, det yngste konkurrencested. Et ofte valgt samlingssted, når store politiske beslutninger skulle meddeles større folkeforsamlinger. Interessant i denne forbindelse er den makedonske kong Filip II's valg til leder af Den Korinthiske Liga her på stedet i 337/336 f.v.t. Palæstra er ikke fundet, men kun 4-5\% af det hellige område er udgravet, og meget er gået tabt, idet romerne totalt $\varnothing$ delagde Korinth i 144 f.v.t. Korinth ledede de isthmiske lege i størstedelen af disse leges historie.

Landevejstemplet til ære for Poseidon er frilagt. De to sportsanlæg, hvor det arkaiske ligger tæt på templet og et senere 250

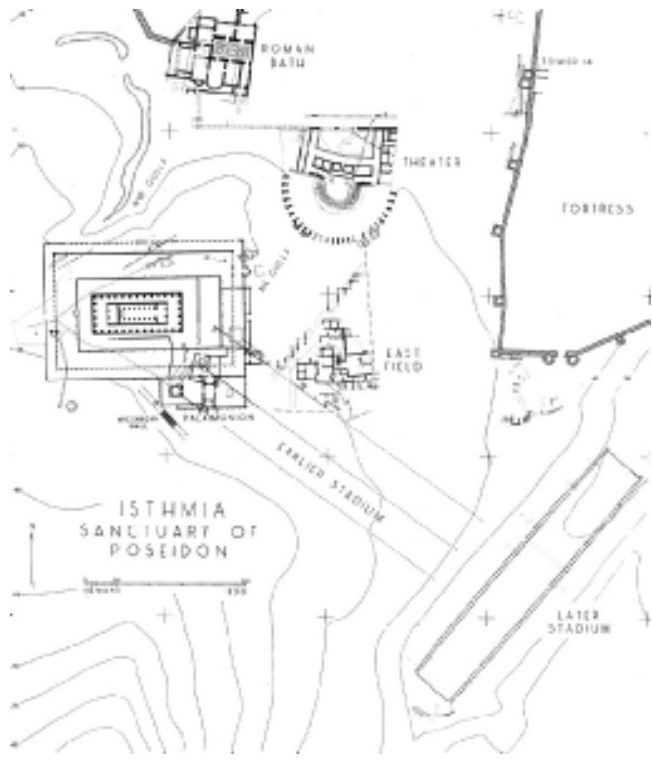

Figur 8: Topografisk plan over Isthmiahelligdommen (Raubitschek).

$\mathrm{m} \emptyset \mathrm{st}$ for templet med udnyttet naturlige højdeforhold til tilskuerpladser, ses nederst på figur 8 . Ud over denne åbenbare hensigtsmæssige flytning, illustrerer anlæggets ændrede placering på ny den adskillelse af kult og sport, der finder sted ved den klassiske periodes udløb. Øverst på figur 8 ses det romerske bad. Amerikanske arkæologer har forestået udgravninger siden 1952 i Isthmia og har nylig afdækket et stort græsk svømmebassin under det romerske bad. Gravearbejdet forestår stadig, og der udsendes hvert år foreløbige rapporter, hvorfra efterfølgende er hentet. ${ }^{54}$ Bassinet, hvis ene side er $30 \mathrm{~m}$ og med en dybde på en $\mathrm{m}$, må have været et markant træk i helligdommen. Professor Samuel B. Fee fra Washington \& Jefferson College har i forbindelse med korrespondance med artiklens forfatter tilkendegivet en stærk formodning om, at palæstra findes øst for det netop udgravede græske bad. Kommende 
udgravninger vil søge at afdækket dette. Det er dog vanskeligt at se muligheden for at placere de knap $200 \mathrm{~m}$ lange xystos og paradromis i dette område. Korinths ledelse og nærhed kan have henlagt træning til et anlæg $\mathrm{i}$ byen, som Elis $\mathrm{i}$ sin tid for Olympia. Korinth har som Athen flere gymnasier, eksempelvis Craneion, som ud over at betjene den mandlige lokalbefolkning muligvis også har kunnet lægge hus til atlettræning. Overdækket og parallelbane er ikke fundet her.

\section{Datering}

Den romerske $\varnothing$ delæggelse af helligdommen har betydet, at der næppe findes indskrifter, der kan bidrage til en datering af sportsanlæg eller muligt træningsanlæg. Arkæologiske fund daterer det simple sportsanlæg ved templet til 575-550 f.v.t. Da Philip II i 338/37 f.v.t. sammenkalder til fællessamling mod perserne sker dette sandsynligvis på et nyt sportsanlæg (se figur 8). Det er ikke usandsynligt, at dette nye anlæg har været led i de store byggeaktivite-

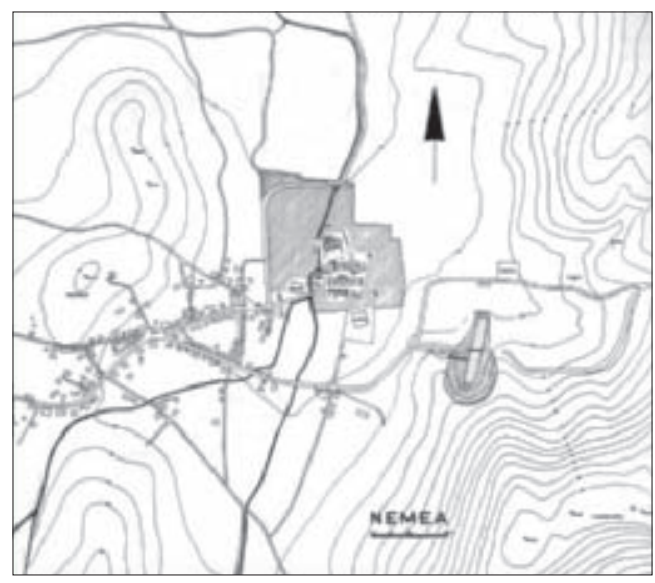

Figur 9: Topografisk kort over Nemeadalen med skraveret udgravningsområde (Miller) ter, som de makedonske erobrere iværksatte i Olympia og Korinth. ${ }^{55}$ Ved anlæggelsen af det yngre sportsanlæg er den doriske/olympiske/peloponnesiske fod forladt og i stedet anvendt en jonisk fod på $0,296 \mathrm{~m} \cdot{ }^{56}$ Selvom om Filip II og Alexander den store ikke havde nogen arkæologisk ideologi, kan der dog iagttages et begyndende brud i den doriske ordens magtposition efter det græske forbunds nederlag ved Chaeronea i 338 f.v.t. Det græske bad, og hvor der muligvis kan afdækkes rester af palæstra, er foreløbigt dateret til det 4. århundrede f.v.t. ${ }^{57}$

Filip II og Aleksander den Store anlagde én af de fire garnisioner i Korinth - militærstrategisk velvalgt og politisk rationel på grund af bystatens antimakedonske holdning før det afgørende slag i 338 f.v.t. Et træningsanlæg ville samtidig kunne opfylde denne kongemagts fordring om træning af en stående makedonsk hærstyrke.

\section{Nemea}

Herakles' drab af den nemiske løve bringer myten om denne udpræget praktiske helts efterlignelsesværdige bedrift som én mulig årsag til etableringen af de nemiske lege $\mathrm{i}$ erindring.

Helligdommen er placeret i Nemeadalen syd for Korinth og vest for Argos.

I Nemea er der to udgravningsfelter som vist på figur 9, nemlig omkring Zeustemplet og omkring sportsanlægget mod syd$\varnothing$ st.

Den amerikanske arkæolog C.W. Blegen mente allerede i 1920'erne at have fundet såvel træningsanlægget som bygningskomplekset syd for Zeustemplet. ${ }^{58}$ Der er her tale om to rektangulære bygninger med en længde på henholdsvis 36 og $85 \mathrm{~m}$ og en bredde på $20 \mathrm{~m}$ adskilt af åbent område - en vej til templet. Den mindste 
bygning mod vest skulle være palæstra. I tre små sektioner rummer den sydligste et græsk bad. Et tilstødende næsten kvadratisk rum i bygningens $\varnothing$ stlige del har midt $\mathrm{i}$ fire tagbærende søjler. Der er ingen peristylgård og alene derfor er det ikke at betegne som en typisk palæstra. Der kan i stedet være tale om et (atypisk) stort træningsrum - dog vanskeliggjort ved placeringen af de fire søjler. Plads til afklædning ville være mulig, men de lige så nødvendige magasiner kan næppe placeres. Nemeavandløbet $g \varnothing r$ det vanskeligt at placere denne bygning som del af et større sammenhængende træningsanlæg.

Den rektangulære bygning $\varnothing$ st herfor betegner Blegen som gymnasion og den kan have tjent som atletbeboelse på grund af fund af sportsrekvisitter, kogegrej mm. De til et træningsanlæg hørende knap $200 \mathrm{~m}$ lange xystos og paradromis mangler imidlertid. En øst/vestgående antik vej og bygninger nord og syd herfor umuliggør også en placering af disse løbebaner.
Som det fremgår af ovenstående kan Blegens formodninger om at have fundet træningsanlæg samt andre bygningsværker betvivles, hvilket de da også er blevet. I dag anses Blegen's identifikationer ved Nemea som ufuldstændige. University of California, Berkeley foretager i disse år en række spændende gravearbejder vest for Nemeafloden og nord for det femkantede heroon. Ifølge foreløbige rapporter fra dette universitet er der fundet en række spor, der antyder en hippodrome i kraft af enkelte hjulspor. Dog har Nemeavandløbet udvasket mange spor. Fundet af et par mindre startblokke peger på et muligt før-hellenistisk sportsanlæg i dette område. ${ }^{59}$ Adgangen til vand og nærheden af hovedgudens tempel har ved andre helligdomme været en af forudsætningerne for den klassiske symbiose mellem sport og kult. De nye udgravninger efter OL 2004 bliver spændende. Er det tænkeligt, at dette område vest for vandløbet har lagt grund til træningsanlægget? Som følge af resultaternes fore-

Figur 10: Grundplan over Zeushelligdommen i Nemea (Berkelys rapporter).

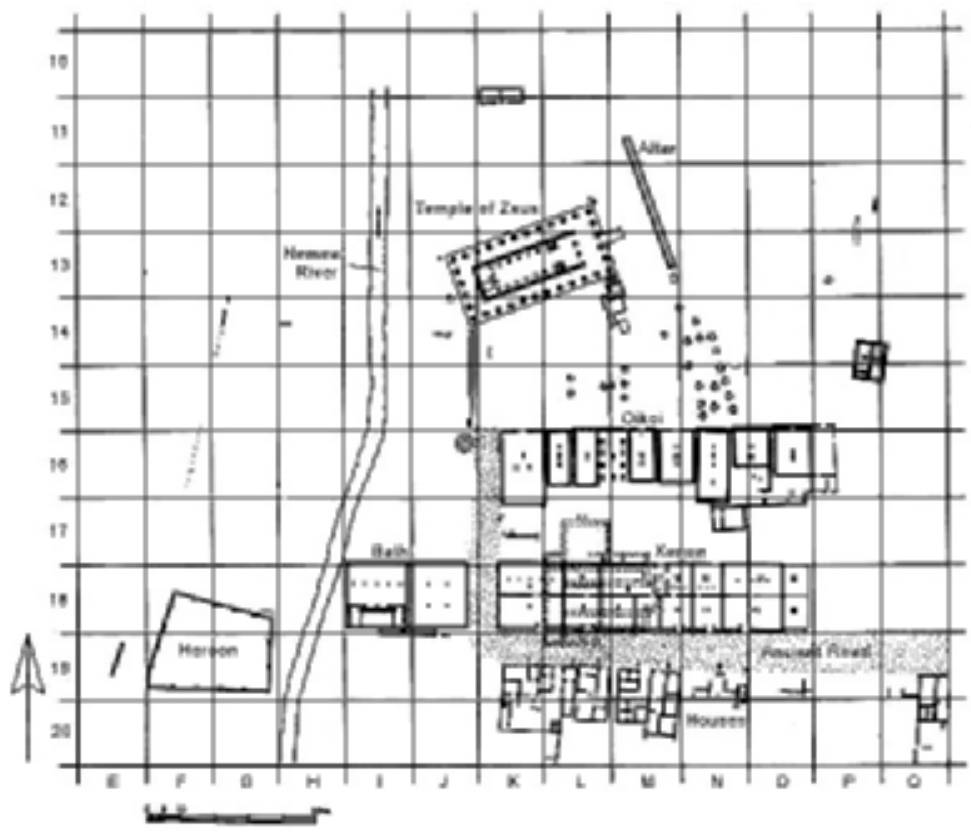


løbige karakter er de endnu ikke indplaceret i grundplanen, figur 10 .

Det for konkurrence nødvendige afklædningsrum, apodyterion, er fundet, identificeret og dateret. Det ligger ved sportsanlægget sydøst for Zeustemplet og er blevet forbundet hertil gennem en tunnel, muligvis som led i et samlet stort byggeri $i$ årene o. 330 f.v.t. ${ }^{60}$ Afklædningsrummet har ikke været sammenbygget med andet byggeri og har derfor ikke været en del af palæstrakomplekset.

Som i Olympia, Delfi og Isthmia udsendte ledelsen af de nemiske lege delegater, theorodokoi, til en række bystater for at $» r e-$ klamere « for egne festivals og træning hertil. ${ }^{61}$ Hvis et træningsanlæg har eksisteret, står identifikation endnu tilbage. I en privat korrespondance i januar 2002 med professor Stephan G. Miller fra Berkeley ytrer han tvivl om, hvorvidt det tidligere nævnte græske bad har været en del af et større træningsanlæg. Tvivlen forstærkes yderligere af, at de nylig fundne startblokke for løb ikke samtidig har kunnet afdække xystos. Tvivlen har altid været den kraftigste stimulans for fortsat søgning. De næste års gravning giver måske svaret på, om Nemea også har haft et træningsanlæg, eller om træningen har været henlagt til den politisk stærkere bystat Argos. Det er måske næppe realistisk at forestille sig, at Nemea kort tid efter sin reetablerede kontrol over legene 0.330 f.v.t. har været i stand til at rejse de nødvendige midler til et træningsanlæg.

\section{Noter}

1. www.perseus.tufts.edu/egi-bin/ttext?doc.

2. Pindar Isthm IV, 28.

3. Paulys (1939) b 4.639.

4. Der er i Olympia, Delfi og Isthmia klar arkæologisk evidens for denne gudinde og hendes datter Kore/Persefone.

\section{De sidste kommentarer}

Det er endnu ikke muligt at fremstille et fuldstændigt samlet billede af træningsanlæg ved O-D-I-N, dels fordi det ikke er sikkert, at ledelserne ved de fire festivals har $\emptyset$ nsket eller $\varnothing$ konomisk været i stand til at rejse en palæstra, dels fordi nogle områder stadig mangler systematisk udgravning. Men panegyriske festivals, hvor prisen var en krans, må have krævet træningsanlæg til rådighed for atleterne. I Olympia og Delfi er disse anlægs karakteristiske kvadratiske bygningsdel fundet med et opførelsestidspunkt $\mathrm{i}$ begyndelsen af den hellenistiske periode og med en ikke usandsynlig samtidighed til sportsanlæggene. Det er imidlertid næppe utænkeligt, at dette har været gældende for alle fire festivals, når legenes status og periodonikernes vidnesbyrd medtænkes. I så fald institutionaliseres træning ved de stefaniske lege omkring hellenismens begyndelse. Tilbage bliver at finde de arkæologiske levn, der kan bekræfte dette samlede billede. Sportens store byggeaktivitet følger et parallelspor til andet stort profant byggeri i hellenismen og betyder samtidig en adskillelse mellem det religiøse og det sportive.

Sportens grundlæggende livsbekræftende idé om en form for tilværelse efter døden udvandes til fordel for sportens selvtilstrækkelighed.

\footnotetext{
5. IGA 380.

6. I en indskrift fra Akraiphiai optræder ordet pane/llhnej [panhellenes] for første gang.

Achaiernes og panhellenernes rådsforsamling $i$ Argos (IG VII 2711-2712).

Det var den romerske kejser Gaia (Caligula),
} 
der tålte forbundet af græske bystater; men det var faktisk først under den romerske filhellener, kejser Hadrian, at panhellenismens blomstringstid begyndte. Due anser Homers enkeltbrug af ordet som et falsum.

7. Artiklen anvender den traditionelle periodisering: Arkaisk periode (700 f.v.t.-479 f.v.t.)

Klassisk periode (479 f.v.t.-323 f.v.t.)

Hellenistisk periode (323 f.v.t.-31 f.v.t.)

Kejserdømmet tidl. (31 f.v.t.-180 e.v.t.)

8. Arkæologiske vidnesbyrd kan ikke bekræfte 776 f.v.t., men anser 704 f.v.t. for mere sandsynlig med en 2-årig periode i starten. Mallwitz (1992) p. 101).

9. Solon institutionaliserer med 100 drachmer en pris for vindere ved de isthmiske lege. De isthmiske og pytiske lege etableres ved den 49. olympiade if. Solinus o. 200 e.v.t. og Eusebius i det tidl. 4 årh. e.v.t.

10. I Isthmia erstattes muligvis på dette tidspunkt begravelseskransen af fyrrenåle med vild selleri som i Nemea.

11. Gebhard E. R. (2002), p. 230.

12. Gebhard E. R. (2002), pp. 221-237.

13. Hjortsø. (1964), pp. 32 \& 136.

14. Trolle S. (1972), p. 15.

15. Sfinx 1981.

16. Danmarks Idræts-Forbund (2000), 11,1 spalte.

17. -tra betegner rum for jeg-handlingen palai/w.

18. Bacchylides Ode 18, str. 2.

19. Herodot Historie VI: 126.

20. Moretti L. (1959), p. 70.

21. Er under udgravning.

22. Platon, Euthydemos 273b.

23. Aischines 1. tale sek. 10.

24. Due O. S. 1983, p. 65.10.

25. Old Oligarck, Athens Forfatning, kap. 2.10.

26. Pausanias VI 23.4.

27. Liddell, H.G. A R. Scott (1940): Greek-English Lexicon.

28. Granger (1955), p. 307.

29. Vitruvius, V 11.1-4.

30. Rowland \& Howe, (1999) p. 6.

31. IV Bericht üb.d.Ausgrabg. in Ol., Arch. Jahrb. (1943/44) pl. 4.

32. Mallwitz A. (1972), p. 278.

33. Svarende til en fodlængde på $30,7 \mathrm{~cm}$, hvilket pe- ger på den hellenistiske periode. Miller anvender en attisk fod på 0,2957 og et jonisk fod på 0,2959 (Nemea II, p. 36: n. 69) Broneer opererer med 5 forskellige fodlængder: Olympisk/peloponnesisk(0,3204); hellenistisk(0,302), jonisk-ro$\operatorname{mer}(0,296)$; attisk $(0,326)$ og lilleasiatisk(0,35).

34. Mallwitz A. (1972), p. 279. Burde vel rettelig være $1: 6,7$ !

35. Mallwitz A. (1972), p. 270.

36. Tomlinson R. A. (1963) pp. 133-145.

37. Mallwitz A. (1972) p. 289.

38. Broneer O. betegner denne fod som »Olympic or Peloponnesian«. Isthmia vol. II p. 64.

39. Efter den amerikanske arkæolog Broneer O., der bl.a. udgravede Poseidontemplet og sportsanlægget.

40. Dinsmoor W. B. (1975), p. 320. En let afvigende hellenistisk fodlængde.

41. Curtius antog den ægyptiske Ptolemaios II (283246 f.v.t.) som bygherre. Wacker C. genoptager denne opfattelse.

42. Hjorts $\varnothing$ L. (1980), p. 41.

43. Yegül F. K. (1995), p. 15.

44. AJA XI 1896, pp. 173-195.

45. Wacker C. (1996), pp 131-133.

46. Worm E. (1997), p. 179.

47. Boolsen P. (1997), p. 271.

48. Delorme J. (1960), p. 378, n. 7.

49. Bankel H. (1983), p.65.

50. Glass (1968) p. 88 n. 268; Det nye Apollontempels stylobatbredde var 80 attiske fod, hvorfor samme måleenhed er sandsynlig med samme bygherre, samme bygmester i samme tid.

51. BCH, 23 p. 564

52. BCH 23 (1899) pp. 564-68; inv. 3862

53. Mussche p.45-46, I Vanhove (1992) baseret på Delorme, Gymnasion 76-80 \& og Jannoray Fouillles de Delphes pp.11

54. www.osu.edu/history/isthmia/grkpool.html.

55. Broneer O. (1973), p. 66.

56. Broneer O. (1973), p. 64.

57. www.osu.edu/history/isthmia/grkpoo.html.

58. Blegen C. (1926), p. 429.

59. www.socrates.berkely.edu/ $\operatorname{clscs} 275 /$ nemeanews.htm.

60. Miller S. G. (2001), p. 178.

61. Hesperia vol 57, no 2 pp. 147-163. 


\section{Litteraturliste}

Aischines. Borgerret og prostitution (Århus, 1983) oversat af Otto Steen Due.

Bankel H. Mitteilungen des Deutschen Archäologischen Institut, Athenische Abteilung, b 98 (Berlin, 1983).

BCH. Bulletin de Correspondance Hellenique 1899-23.

Bender J., Brok A. \& Jørgensen P. På sporet af det olympiske (Brøndby, 2000).

Birge D. E., Kraynak L. H. \& Miller S. G. Excavations at Nemea (Berkeley, 1992).

Blegen C. Excavations at Nemea. AJA XXXI 1926, pp. 429-440.

Bommelaer J-F. Guide de Delphes, Le Site (Paris, 1991).

Boolsen P. Delfi - glemt og genfundet. I: Wagner O. (red.) Delfi tekster og artikler om Apollons helligdom (Odense, 1997), pp. 261-282.

Broneer O. Isthmia Vol II- Topography and Architecture (New Jersey, 1973).

Delorme J. Gymnasion, Étude sur les monuments consacres à l'education en Grèce, (Paris, 1960).

Dinsmoor W. B. The Architecture of Ancient Greece, (New York, 1975).

Gebhard E. R. The beginning of Panhellenic Games at the Isthmus. Akten des Internationalen Symposions Olympia 1875-2000 (Berlin, 2002).

Glass S. L. Palaistra and gymnasium in Greek Architecture (Michigan, 1968).

Hastrup \& Hjorts $\varnothing$ Herodots Historie bog I-IV \& bog V-IX, (København, 1979).

Hjortsø L. Den grceske olympiade. Sfinx 1980 pp. 4145.

Hjortsø L. Olympia - Den graske olympiade (København, 1964).

$\mathrm{IG}=$ Inscriptiones Graecia (1924-)

Lauter H. Die Arkitektur des Hellenismus (Darmstadt, 1986).

Mallwitz A. Olympia und seine Bauten (München, 1972)

Marinatos N. \& Hägg R. Greek Sanctuaries New approaches (London, 1993).

Miller S. G. (AJA 84 1980).

Miller S. G. Excavations at Nemea II (Berkeley, 2001).

Miller S. G. Nemea A Guide to the Site and Museum (Berkeley, 1990).

Miller S. G. Excavasions at Nemea. Hesperia 47, 49, $50,53$.
Moretti L. Olympianikai. Atti della Accademia Nationale dei Lincei. Memorie. Classe di Scienze (Rom, 1959).

Müller-Wiener W. Griechiesches Bauwesen in derAntike Palaistra-Gymnasion, (München, 1988).

Nielsen I. Sportsanlacg. I: Westergård-Nielsen N. m. fl (red.) Den græske olympiade, pp 24-32 (Århus, 1980).

Ohio State University (gennemset august 2003) Excavations Isthmia (www.osu.edu/history/isthmia).

Pantazos E. Le gymnase. Delphes. Centenaire de la grande fouilles realise par I'Ecole francaise d'Athenes, 1892-1903, pp. 225-232 (Leiden, 1992).

Perseus Collections (gennemset september 2003) (www.Perseus.mpiwg-berlin.mpg.de/egi).

Raubitschek I. K. Isthmia VII The metal Objects (1952-1989) (New Jersey, 1998).

Richardson R. B. \& Heermance T. W. Inscriptions from Eretria. AJA XI 1896, pp. 173-195.

Tomlinson R. A. The Doric Order: Hellenistic Critics and Criticism. The Journal og Hellennic Studies nr. $82-1963$.

Trolle S. Fra kultidrat til sportskult i Grakenland og Rom. I: Nielsen H. (red) For sportens skyld, pp 1534 (København 1972).

Tzachou-Alexandri O. (red). Mind and Body (Athens, 1989).

Vanove E. D. (red). Le Sport dans la Grèce Antique (Gent, 1992).

Vitruvius P. De Architectura libri decem (Harvard, 1955) - oversat af Frank Granger.

Wacker C. Das Gymnasion in Olympia, Geschichte und Funktion (Würzburg, 1996).

Wien C. N. Det graeske gymnasion, Funktion og Form belyst ved udvalgte eksempler (Odense, 1990).

Wissowa (red.). Paulys Realencyclopädie der classischen Alterturnswissenschaft (9. udg.) (Stuttgart, 1939).

Worm E. Med Pausanias i Delfi. I: Wagner O. (red) Delfi tekster og artikler om Apollons helligdom, pp 159-240 (Odense 1997).

Yegül F. K. Bath and bathing in classical antiquity (Rome, 1992).

Zschietzschmann W. Wettkampf- und Übungstätten in Griechenland. Stadion, Palaistra, Gymnasion. Eine Übersicht, 2. (Stuttgart, 1961). 